\title{
The Development of Science Learning Tool Oriented Toward Guided Inquiry to Improve Students' Critical Thinking Skills
}

\author{
${ }^{1}$ Rahmi NurHabibah, ${ }^{2}$ Tjandra Kirana, ${ }^{3}$ Raharjo \\ ${ }^{1}$ Post Graduate, State University of Surabaya, ${ }^{2}$ Lecturer, State University of Surabaya, ${ }^{3}$ Lecturer, State University of Surabaya
}

\begin{abstract}
This study aims to produce science learning tools that are valid, practical, and effective which consists of syllabus, lesson plan, teaching material, student activity sheets, and test sheets to improve the critical thinking skills of elementary students. This research was carried out using the 4-D model of adaptation Ibrahim, M., which is define, design, developing, disseminate and tested in class $\mathrm{V}$ of Jiken Elementary School, Kedondong I Elementary School, Sudimoro Elementary School, school year 2019/2020 with One-Group Pretest-Posttest Design. Data analysis techniques used are quantitative and qualitative descriptive. The results shows: 1) valid, according to the validity of the three validators with valid categories, 2) practical, in accordance with the level of observers seen from the activity of students increasing at each meeting and implementation of RPP, 3) effective, seen from appearing significantly different from the pretest and posttest test students' critical thinking and positive student responses. Based on the results of data analysis, it can be concluded that the development of science learning tools oriented in guided inquiry is valid, practical, and effective for improving critical thinking skills of elementary students.
\end{abstract}

Keywords:- Development of Learning Tools, Guided Inquiry, Critical Thinking Skills.

\section{INTRODUCTION}

The development of Science and Technology in this globalization era require quality Human Resources, one of several ways is through education process. Education is needed to prepare human resources in facing the challenges of the 21 st century. Science learning has the potential to prepare human resources who are ready to face the era of globalization, technological science and education. Science is said to have the potential because it emphasizes the provision of direct learning experiences through a series of scientific processes so as to achieve the goals set. The emphasis aims to improve the ability of students. The ability of students in the science learning process is able to develop critical thinking skills, creative, initiative, and adaptive to change and development (Trihastuti, 2008). Such abilities are needed in modern science learning (Iskandar in Neka et al 2015). The science problems are important for the students because they are related to the surrounding natural environment. It means that science has objective and rational nature. In line with the opinion of Bundu (2006: 11) in general, the nature of science consists of three components, including the processes carried out scientifically, the results of scientific products, and scientific attitudes. Science learning must emphasize mastery of competencies through a series of scientific processes and problem solving so the students can understand the learning concept more easily.

When solving the problems, the students are expected to be able to solve them with useful mindsets and appropriate solutions. Marzano (in Morgan, 1999) points out the importance of thinking learning, which are: (1) thinking is needed as a way of developing perceptions and attitudes that support for the creation of a classroom condition which is good for learning activities; (2) thought processes are needed as a way to acquire and integrate knowledge; (3) the thought process is needed to add insight knowledge; (4) actualizing the meaningfulness of knowledge; (5) needed as a way to develop beneficial thinking behavior. By Using science education students will be guided to think critically, solve problems, and make decisions that can improve their quality of lifex towards a scientifically learned society. The ability to think critically is the ability of students to make an idea. The ability to think critically is a competency needed in the lives of students (Schafersman in Arnyana, 2004). According to Krulick and Rudnick (1999), critical thinking is a way of thinking that tests, connects, and evaluates all aspects of a problem situation, including the ability to gather information, remember, analyze situations, read, understand and identify required things. In the other hand, the opinion of Ennis (1995) states there are six basic elements that need to be considered in critical thinking, namely: focus, reason, conclusion, situation, clarity and overall examination.

People who think critically will decide and think rationally through several views of a different context. Critical thinking is needed to solve a problem faced by an individual. A person with a critical thinking will be able to summarize the information he knows, can use the information obtained to solve the problem, and find information that is relevant to the problem he has. The development of critical thinking skills of students is very important should receive more attention in the learning process. The ability to think critically must first be taught because it relates to the analysis and evaluation of data (Hake, 2008). Based on observations and interviews conducted by researchers in the science learning activities at 
SDN Kedondong 1, SDN Sudimoro, and SDN Jiken in the odd semester of the 2019/2020 school year it was found several causes have not been maximized in the effort of practicing critical thinking to students in science learning because : (1) teachers have difficulty dealing with students with unequal abilities and lack of science learning motivation; (2) students have difficulty using critical thinking skills because they are not familiar; (3) the unavailability of learning that can practice critical thinking skills for students. The absence of appropriate and supportive learning causes difficulties in seeking an increase in students' critical thinking.

Based on the description above, students are expected to have maximum thinking skills. However, in reality students' critical thinking skills are low, so it is the mismatch between expectations and this reality that causes problems. Therefore, the learning process in the classroom must be designed in such a way as to improve students' thinking, one of the efforts to solve these problems is by developing guidelines for teachers in learning tools to use a learning model as a support to the learning process that emphasizes the provision of experiential experience directly and be able to improve students' critical thinking skills. The type of model the researcher will use is inquiry learning model. Learning inquiry model is a learning model that fosters the ability to think, work, and be scientific. The inquiry learning model is very compatible with science learning. The inquiry learning model provides the opportunity for students to gain an understanding of the scientific method to develop critical thinking skills, self-regulation, and understanding of specific topics (Eggen, 2012). Inquiry learning that is appropriate for elementary school age is Guided Inquiry learning or Guided Inquiry, because children at primary school age have not much experience with inquiry learning (Udiani, 2017).

Jerome Bruner in Neka (2015) stated four reasons for using Guided inquiry learning, namely: intellectual potential, intrinsic motives, heuristic inquiry learning, and memory conservation. with intellectual potential, Bruner states that an individual learns and develops his mind only by using his potential. Bruner stressed that people who learn inquiry techniques have the opportunity to discover by themselves. Through Guided Inquiry, students will slow down their learning so they can organize and conduct investigations properly. The biggest result in Guided inquiry is that learning will help with memory retention and can be applied easily to new situations. if students find or build knowledge independently, then the knowledge acquired will be remembered for longer. Glaser's research shows that Guided Inquiry learning strongly supports students 'development in problem solving, creativity, independent learning and students' thinking skills (Redhana, 2009).
Guided Inquiry learning model as an alternative needs to be developed to achieve the basic competencies that must be achieved in practicing students' critical thinking skills. The basic competency that must be achieved in the 2013 curriculum is that students are required to be able to think at a high level, namely analyzing the water cycle and human life. This material is a complex material for students so that understanding the material of the water cycle and human life is not only enough to read the description of the material alone, but it is necessary to conduct an inquiry or experiment so that students' understanding of the material gets deeper. Material of the water cycle and human life of class V Elementary School includes analyzing the process of the water cycle, describing the impact of human activities on the water cycle on the earth, and suggests ways to conserve water. Based on these sub-materials, that the material characteristics of the water cycle and human life can be learned by applying Guided Inquiry learning because each phase of the Guided Inquiry model is largely an indicator of critical thinking skills that are trained in this study. So by learning the Guided Inquiry model, students are expected to be able to develop their critical thinking skills to solve a problem that is encountered in daily life through scientific activities or investigations. Based on the background above, it is necessary to develop learning devices designed in such a way as to improve students' critical thinking skills through a development study entitled "Development of Science Learning Tools Oriented on Guided Inquiry to Improve Critical Thinking Skills of Elementary School Students".

\section{METHOD}

The trial was conducted using one group pretestposttest design with 3 repetitions, namely 5 students at SDN Jiken, 6 students at SDN Kedondong 1, and 4 students at SDN Sudimoro grade $\mathrm{V}$ in elementary school for 4 meetings. The first meeting is used pretest to find out the students' initial critical thinking skills before learning activities using Guided Inquiry oriented learning tools, the second and third meetings are used for learning activities using Guided Inquiry oriented learning tools, and the fourth meeting is used posttest to know the final critical thinking abilities students after participating in learning activities. The research variables in this study are 1 . the validity of learning tools validated by experts, 2 . practicality as seen from the results of observations / observations of the implementation of lesson plans and student activities, 3. Effectiveness which is seen from the results of tests increasing critical thinking of students. 


\section{RESULTS AND DISCUSSION}

\section{A. Development Result}

The results of research on the development of science learning tools oriented Guided Inquiry in improving critical thinking skills associated with the results of the implementation of limited scale trials. The science learning tools that have been developed have been refined based on the guidance of the supervisor and the validation results of the validator from three expert lecturers in their field. The limited trial research was carried out using an online face-toface system (in a network) with the ZOOM platform. Online face-to-face learning is based on students' obligations to Study Form Home (SFH) in semester 2 from March 2020.

The limited trial was conducted with three repetitions, namely 4 Jiken SDN students, 6 Kedondong SDN students, and 5 Sudimoro SDN grade 5 students each and held 4 online meetings. The first meeting is used to provide pretest questions in order to determine the students' initial ability to think critically. The second and third meetings are used as a learning process by using Guided Inquiry oriented science learning tools, and the fourth meeting is used to distribute posttests to determine students' final critical thinking skills after learning with the Guided Inquiry learning tool that has been developed.

Development of Guided Inquiry oriented science learning tools to improve critical thinking skills consisting of syllabi, lesson plans, teaching materials, LKPD and critical thinking tests.

\section{B. Validation Result of Learning Tool}

The results of the validation of the learning tools that have been developed are validated by three expert lecturers consisting of syllabus, learning device plans, teaching materials, student worksheets, and critical thinking tests.

\section{Validation of Silabus}

The syllabus developed for this research was made for two meetings. The validation results from the validator get suggestions for improvement. Then the revisions were made according to the suggestions and input from the validator. Suggestions from validators are explained below. Syllabus validation results obtained from 3 validators are presented in Table 1.

\begin{tabular}{|c|c|c|c|c|c|c|}
\hline \multirow{2}{*}{ No } & Assessment & \multicolumn{3}{|c|}{ Score } & \multirow{2}{*}{ Average } & \multirow{2}{*}{ Category } \\
\cline { 3 - 5 } & Aspect & $\mathbf{V}_{\mathbf{1}}$ & $\mathbf{V}_{\mathbf{2}}$ & $\mathbf{V}_{\mathbf{3}}$ & & \\
\hline 1 & Content & 3 & 4 & 3.2 & 3.4 & Valid \\
\hline 2 & Language & 3 & 3 & 3 & 3 & Valid \\
\hline 3 & Time & 3 & 4 & 4 & 3.7 & $\begin{array}{c}\text { Very } \\
\text { Valid }\end{array}$ \\
\hline
\end{tabular}

Table 1:- Syllabus Validation Result

Based on Table 1, based on the syllabus validation score obtained in each aspect, if it is associated with the validation assessment category according to Ratuman and Laurens (2016) shows that the syllabus developed is included in the valid category with a slight revision. Based on the results of validation, the syllabus is declared valid because the syllabus component is fulfilled. This is in accordance with the syllabus component consisting of subject identity, school identity, core competencies, basic competencies, learning material, assessment, time allocation and learning resources (Permendikbud number 22, 2016). The results of syllabus validation that have been developed show that the tendency of syllabus validity is valid so that the syllabus developed has fulfilled good syllabus development criteria so that it can be used for the next development stage.

\section{Validation of Learning Implementation Plan}

The lesson plans developed for this study were made for two meetings and adjusted to online learning conducted by researchers. The validation results from the validator get suggestions for improvement. Then the revisions were made according to the suggestions and input from the validator. Suggestions from validators are explained in Table 2.

\begin{tabular}{|c|c|c|c|c|c|c|}
\hline \multirow{2}{*}{ No } & \multirow{2}{*}{$\begin{array}{c}\text { Assessment } \\
\text { Aspect }\end{array}$} & \multicolumn{3}{|c|}{ Score } & \multirow{2}{*}{ Average } & \multirow{2}{*}{ Category } \\
\hline & & $\mathrm{V}_{1}$ & $V_{2}$ & $\mathbf{V}_{3}$ & & \\
\hline 1 & Identity & 4 & 4 & 4 & 4 & $\begin{array}{l}\text { Very } \\
\text { Valid }\end{array}$ \\
\hline 2 & Purpose & 4 & 4 & 3 & 3,67 & $\begin{array}{l}\text { Very } \\
\text { Valid }\end{array}$ \\
\hline 3 & $\begin{array}{l}\text { Guided } \\
\text { Inquiry }\end{array}$ & 3 & 4 & 3 & 3,33 & Valid \\
\hline 4 & $\begin{array}{l}\text { Facility and } \\
\text { Learning } \\
\text { Resource }\end{array}$ & 3 & 4 & 4 & 3,67 & $\begin{array}{l}\text { Very } \\
\text { Valid }\end{array}$ \\
\hline 5 & Learning Plan & 3 & 4 & 3 & 3,33 & Valid \\
\hline 6 & $\begin{array}{l}\text { Assessment } \\
\text { Procedure }\end{array}$ & 3 & 3 & 3 & 3 & $\begin{array}{l}\text { Very } \\
\text { Valid }\end{array}$ \\
\hline 7 & Language & 3 & 3 & 3 & 3 & Valid \\
\hline
\end{tabular}

Table 2:- Validation Result of RPP

Based on the results of validation above, it can be seen that the three validators provide an assessment that the RPP in every aspect with a tendency to validity of the RPP is very valid. These results when related to the learning device assessment criteria adapted from Ratuman \& Laurens (2016) show that the lesson plans that were developed included in the value category are very valid and can be used in learning.

\section{Validation of Teaching Material}

Teaching material developed for this research is in the form of student learning resources related to the material of the water cycle and human life for grade V of elementary school. Teaching materials used for students as a reference to add information for learning Guided Inquiry are presented in the form of soft files that are distributed before learning begins. The results of the validation of teaching materials from the validator get suggestions for improvement. Then the revisions were made according to the suggestions and input from the validator. Suggestions from validators are explained in Table 3. 
ISSN No:-2456-2165

\begin{tabular}{|c|c|c|c|c|c|c|}
\hline \multirow{2}{*}{ No } & \multirow{2}{*}{ Assessment Aspect } & \multicolumn{3}{|c|}{ Score } & \multirow{2}{*}{ Avg } & \multirow{2}{*}{ Category } \\
\hline & & $\mathbf{V}_{1}$ & $\mathbf{V}_{2}$ & $\mathbf{V}_{3}$ & & \\
\hline \multicolumn{7}{|c|}{ Content } \\
\hline 1 & Material compatibility with KD & 3 & 3.3 & 3 & 3.1 & Valid \\
\hline 2 & Material accuracy & 3 & 3.6 & 3.4 & 3.3 & Valid \\
\hline 3 & Material Updates & 3 & 4 & 3.5 & 3.5 & Very Valid \\
\hline 4 & Encourage curiosity & 3 & 3.5 & 4 & 3.5 & Very Valid \\
\hline \multicolumn{7}{|c|}{ Presentation } \\
\hline 5 & Technique & 3 & 3 & 3 & 3 & Valid \\
\hline 6 & Supporting Presentation & 3 & 3.4 & 3.6 & 3.3 & Valid \\
\hline 7 & Learning Presentation & 3 & 3 & 3 & 3 & Valid \\
\hline 8 & Coherence and grooves of thought & 3 & 3.5 & 3 & 3.2 & Valid \\
\hline \multicolumn{7}{|c|}{ Language } \\
\hline 9 & Straightforward & 3 & 3.3 & 3.0 & 3.1 & Valid \\
\hline 10 & Communicative & 3 & 3.5 & 4.0 & 3.5 & Very Valid \\
\hline 11 & Dialogical and interactive & 3 & 3 & 3 & 3 & Valid \\
\hline 12 & Conformity with the development of students & 3 & 4 & 4 & 3,67 & Very Valid \\
\hline 13 & Conformity with language rules & 3 & 3 & 3 & 3 & Valid \\
\hline \multicolumn{7}{|c|}{ Graphical } \\
\hline 14 & Size of teaching material & 3 & 4 & 3 & 3.3 & Valid \\
\hline 15 & Cover design & 3 & 3.8 & 3 & 3.3 & Valid \\
\hline 16 & Cover illustration & 3 & 4 & 3 & 3,33 & Valid \\
\hline 17 & Consistent layout & 3 & 4 & 3.5 & 3.5 & Very Valid \\
\hline 18 & Typography of book content for easy understanding & 3 & 4 & 3 & 3,33 & Valid \\
\hline 19 & Illustration of contents & 3 & 3 & 3 & 3 & Valid \\
\hline
\end{tabular}

Table 3:- Validation Result of Teaching Material

Based on the score of validation of teaching materials obtained in each aspect, if it is associated with the validation assessment category according to Ratuman and Laurens (2016) shows that the teaching material developed is included in the valid category with little revision. The revision of teaching materials carried out according to the suggestions of the validator is to emphasize the steps of inquiry and add pictures to clarify the meaning. This is supported by what Weidenman stated in the book Lehren mit Bildmedien states that reading and listening have a lower meaning than students see photos or pictures (MONE, 2008).

\section{Student Worksheet Validation}

The LKPD that was developed for this study was used to train students' ability to think critically tailored to be packaged in Guided Inquiry-oriented discovery activities. LKPD validation results from the validator get suggestions for improvement. Then the revisions were made according to the suggestions and input from the validator. LKPD validation results obtained from 3 validators are presented in Table 4 below.

\begin{tabular}{|c|c|c|c|c|c|c|}
\hline \multirow{2}{*}{ No } & Assessment & \multicolumn{3}{|c|}{ Score } & \multirow{2}{*}{ Average } & Category \\
\cline { 3 - 6 } & Aspect & $\mathbf{V}_{\mathbf{1}}$ & $\mathbf{V}_{\mathbf{2}}$ & $\mathbf{V}_{\mathbf{3}}$ & & \\
\hline 1 & $\begin{array}{c}\text { Didactic } \\
\text { requirements }\end{array}$ & 4 & 3.5 & 4 & 3,8 & $\begin{array}{c}\text { Valid } \\
\text { Valid }\end{array}$ \\
\hline 2 & Construction & 3.0 & 3.7 & 3.6 & 3.4 & Valid \\
\hline 3 & Technical & 3.5 & 3.0 & 3.0 & 3.2 & Valid \\
\hline
\end{tabular}

Table 4:- Validation Result of LKPD

Based on the LKPD validation score obtained in each aspect, if it is associated with the validation assessment category according to Ratuman and Laurens (2016) shows that the developed LKPD is included in the valid category.

\section{Validation of Students' Critical Thinking Tests}

The critical thinking test developed was validated based on two categories namely content and writing, language. Content validation is explained based on the suitability of the problem with the device developed. Writing validation is based on conformity with the learning objectives. The validation results from the validator get suggestions for improvement. Then the revisions were made according to the suggestions and input from the validator. Suggestions from validators are explained in Table 5. 
ISSN No:-2456-2165

\begin{tabular}{|c|c|c|c|c|c|c|c|c|c|c|c|c|c|c|c|c|c|c|c|}
\hline \multirow{3}{*}{$\begin{array}{c}\text { Q. } \\
\text { No }\end{array}$} & \multicolumn{6}{|c|}{ Content Validation } & \multirow{3}{*}{ Avg } & \multirow{3}{*}{ Category } & \multicolumn{9}{|c|}{ Language and Writing Questions } & \multirow{3}{*}{ Avg } & \multirow{3}{*}{ Category } \\
\hline & \multicolumn{3}{|c|}{$\begin{array}{c}\text { The } \\
\text { questions are } \\
\text { in } \\
\text { accordance } \\
\text { with the } \\
\text { indicators }\end{array}$} & \multicolumn{3}{|c|}{$\begin{array}{l}\text { Problem } \\
\text { measuring } \\
\text { Critical } \\
\text { thinking }\end{array}$} & & & \multicolumn{3}{|c|}{$\begin{array}{l}\text { The work } \\
\text { instructions } \\
\text { are clear }\end{array}$} & \multicolumn{3}{|c|}{$\begin{array}{l}\text { Does not } \\
\text { contain } \\
\text { multiple } \\
\text { meanings }\end{array}$} & \multicolumn{3}{|c|}{$\begin{array}{l}\text { The sentence } \\
\text { is according } \\
\text { to EYD and } \\
\text { easy to } \\
\text { understand }\end{array}$} & & \\
\hline & V1 & V2 & V3 & V1 & V2 & V3 & & & V1 & V2 & $\mathbf{V 3}$ & V1 & V2 & V3 & V1 & V2 & $\mathbf{V 3}$ & & \\
\hline 1 & 3 & 4 & 4 & 4 & 4 & 4 & 3,8 & Very Valid & 4 & 4 & 4 & 3 & 4 & 3 & 3 & 3 & 3 & 3,4 & Valid \\
\hline 2 & 3 & 4 & 3 & 4 & 4 & 3 & 3,5 & Valid & 4 & 4 & 2 & 3 & 4 & 3 & 3 & 3 & 3 & 3,2 & Valid \\
\hline 3 & 3 & 4 & 3 & 4 & 4 & 3 & 3,5 & Valid & 4 & 4 & 2 & 3 & 4 & 3 & 3 & 3 & 3 & 3,2 & Valid \\
\hline 4 & 3 & 4 & 3 & 4 & 4 & 3 & 3,5 & Valid & 3 & 4 & 2 & 3 & 4 & 3 & 3 & 3 & 3 & 3,1 & Valid \\
\hline 5 & 4 & 4 & 3 & 4 & 4 & 3 & 3,6 & Valid & 3 & 4 & 4 & 3 & 4 & 3 & 3 & 3 & 3 & 3,3 & Valid \\
\hline 6 & 3 & 4 & 3 & 3 & 4 & 3 & 3,3 & Valid & 3 & 4 & 3 & 3 & 4 & 3 & 3 & 3 & 3 & 3,2 & Valid \\
\hline
\end{tabular}

Table 5:- Critical Thinking Test Results Validation

Based on Table 5, the results of the validation of the critical thinking test on the component of content validity that have been developed show that the evaluation of the validator with a very valid category is 1 question and the valid category is 5 questions. In the Language component and writing questions developed by researchers received an assessment of the validator with a valid category of 6 questions. Based on the thinking test validation score obtained in each aspect, if it is associated with the validation assessment category according to Ratuman and Laurens (2016) shows that the critical thinking test sheet developed is included in the valid category.

\section{Practical Results of Science Learning Tool Guided Inquiry}

The practicality of science-oriented Guided Inquiry learning tools developed by researchers can be seen from the implementation of learning that is driven by the steps in the learning implementation plan and the implementation of learners' activities in limited trials which in the learning process are carried out online by using the ZOOM platform and observed by two observers . According to Barbosa (in Gunawan, et al 2020) ZOOM allows all students to see and hear each classmate and discuss using any device so as to facilitate the learning process.

\section{Learning Outcomes Results}

The results of observations on the implementation of learning by using Guided Inquiry oriented science learning tools that have been developed will be analyzed at each meeting which is explained in detail as follows.

\begin{tabular}{|c|c|c|c|c|c|}
\hline \multirow{2}{*}{ No } & \multirow{2}{*}{ Observation Aspects } & \multicolumn{2}{|c|}{ First Meeting } & \multicolumn{2}{|c|}{ Second Meeting } \\
\hline & & Average & Category & Average & Category \\
\hline \multicolumn{6}{|c|}{ INITIAL ACTIVITY } \\
\hline \multicolumn{6}{|c|}{ Get attention and do the inquiry process } \\
\hline \multirow[t]{3}{*}{1.} & a. The teacher opens learning through the ZOOM platform & 3.7 & Very Good & 4 & Very Good \\
\hline & b. The teacher makes apperception through the ZOOM platform & 3.5 & Good & 4 & Very Good \\
\hline & $\begin{array}{l}\text { c. The teacher conveys the learning objectives of the ZOOM } \\
\text { platform }\end{array}$ & 3.8 & Very Good & 4 & Very Good \\
\hline \multicolumn{6}{|c|}{ CORE ACTIVITIES } \\
\hline \multicolumn{6}{|c|}{ Presenting the problem of inquiry } \\
\hline \multirow[t]{2}{*}{2.} & $\begin{array}{l}\text { a. The teacher presents inquiry problems through the ZOOM } \\
\text { platform }\end{array}$ & 3,3 & Good & 4 & Very Good \\
\hline & $\begin{array}{l}\text { b. Learners discuss problems from teachers through the ZOOM } \\
\text { platform }\end{array}$ & 3,2 & Good & 3,5 & Very Good \\
\hline \multicolumn{6}{|c|}{ Formulate a hypothesis } \\
\hline \multirow[t]{2}{*}{3.} & $\begin{array}{l}\text { a. Students and teachers conduct question and answer questions } \\
\text { related to inquiry through the ZOOM platform }\end{array}$ & 3 & Good & 3,8 & Very Good \\
\hline & b. Students formulate hypotheses through the ZOOM platform & 2,7 & Good & 3,3 & Good \\
\hline \multicolumn{6}{|c|}{ Gather data and prove hypotheses } \\
\hline \multirow[t]{2}{*}{4.} & $\begin{array}{l}\text { a. Conducting trial activities on LKPD through the Google Form } \\
\text { platform }\end{array}$ & 3,3 & Good & 4 & Very Good \\
\hline & $\begin{array}{l}\text { b. Communicate the results of experiments through the ZOOM } \\
\text { platform }\end{array}$ & 3,3 & Good & 4 & Very Good \\
\hline
\end{tabular}


ISSN No:-2456-2165

\begin{tabular}{|c|c|c|c|c|c|}
\hline \multirow{3}{*}{ No } & \multirow{2}{*}{ Observation Aspects } & \multicolumn{2}{|c|}{ First Meeting } & \multicolumn{2}{|c|}{ Second Meeting } \\
\hline & & \multirow{2}{*}{$\begin{array}{c}\text { Average } \\
3,3 \\
\end{array}$} & \multirow{2}{*}{$\begin{array}{c}\text { Category } \\
\text { Good }\end{array}$} & \multirow{2}{*}{$\begin{array}{c}\text { Average } \\
3,8\end{array}$} & \multirow{2}{*}{$\begin{array}{c}\text { Category } \\
\text { Very Good }\end{array}$} \\
\hline & $\begin{array}{l}\text { c. Questions and answers related to experiments through the } \\
\text { ZOOM platform }\end{array}$ & & & & \\
\hline \multicolumn{6}{|c|}{ Formulate explanations and conclusions } \\
\hline 5. & $\begin{array}{l}\text { a. Learners formulate the conclusions of learning activities } \\
\text { through the ZOOM platform }\end{array}$ & 3 & Good & 3,5 & Good \\
\hline \multicolumn{6}{|c|}{ END ACTIVITIES } \\
\hline \multicolumn{6}{|c|}{ Reflecting on a problem situation } \\
\hline \multirow[t]{3}{*}{6.} & $\begin{array}{l}\text { a. teachers and students reflect today's learning through the } \\
\text { ZOOM platform }\end{array}$ & 3,3 & Good & 4 & Very Good \\
\hline & $\begin{array}{l}\text { b. The teacher gives learning feedback and conducts questions } \\
\text { and answers through the ZOOM platform }\end{array}$ & 3,8 & Very Good & 4 & Very Good \\
\hline & c. The teacher closes learning through the ZOOM platform & 3,8 & Very Good & 4 & Very Good \\
\hline
\end{tabular}

Table 6:- Observation Results of Learning Implementation

The results of observations on the implementation of learning activities get the percentage of the implementation of the RPP of the first meeting by observer 1 obtaining an average of 3 repetitions by $74 \%$ and observer 2 obtaining an average of 3 repetitions by $72 \%$. So the average learning outcomes at the first meeting is $73 \%$. The percentage of implementation of the RPP of the second meeting by observer 1 obtained an average of 3 repetitions by $74 \%$ and observer 2 obtained an average of 3 repetitions by $97 \%$. So the average learning outcomes at the first meeting is $96 \%$. With a tendency to assess the practicality of the implementation of the RPP is very good. The results of observations of the implementation of learning from meetings 1 and 2 if it is associated with the criteria of adoption of learning adoption (Sugiyono, 2016, p.93), it was found that the use of teaching materials oriented towards the scientific approach included in the category of assessment carried out well in learning activities.

\section{Analysis Results of Student Activities}

The results of observations of the implementation of student activities when online learning activities using Guided Inquiry-oriented science learning tools that have been developed will be analyzed at each meeting described in detail in the following table.

\begin{tabular}{|c|c|c|c|c|c|}
\hline \multirow{2}{*}{ No. } & \multicolumn{2}{|c|}{ The observed aspect } & \multicolumn{2}{|c|}{ First Meeting } & \multicolumn{2}{|c|}{ Second Meeting } \\
\cline { 2 - 5 } & Percentage & Category & Percentage & Category \\
\hline 1 & Make a question / formulation of the problem & $54 \%$ & Good & $88 \%$ & Very Good \\
\hline 2 & $\begin{array}{c}\text { Make hypotheses a temporary answer from the } \\
\text { formulation of the problem }\end{array}$ & $54 \%$ & Good & $79 \%$ & Very Good \\
\hline 3 & Doing questions and answers & $75 \%$ & Very Good & $100 \%$ & Very Good \\
\hline 4 & $\begin{array}{c}\text { Read teaching materials to find important } \\
\text { information }\end{array}$ & $83 \%$ & Very Good & $100 \%$ & Very Good \\
\hline 5 & $\begin{array}{c}\text { Conduct experiments / observations according to } \\
\text { LKPD instructions }\end{array}$ & $96 \%$ & Very Good & $100 \%$ & Very Good \\
\hline 6 & Present the results of an experiment & $92 \%$ & Very Good & $96 \%$ & Very Good \\
\hline 7 & Asking questions / ideas & $75 \%$ & Very Good & $83 \%$ & Very Good \\
\hline 8 & Conclude & $75 \%$ & Very Good & $96 \%$ & Very Good \\
\hline 9 & Evaluating learning outcomes & $79 \%$ & Very Good & $96 \%$ & Very Good \\
\hline
\end{tabular}

Table 7:- Observation Results on Student Activities

In the learning activities of the first meeting, the activities of the students of the first meeting get a score of two observers each repetition summed overall in every aspect of learning at the first meeting get a percentage of between $54 \%$ to $96 \%$ and in the learning activities of the second meeting, the activities of the students of the second meeting get the scores of the two observers per repetition were summed overall for each aspect of learning at the second meeting getting a percentage of $79 \%$ to $100 \%$. In summary, observations of students' activities during 2 meetings can be displayed in Figure 1 below. 


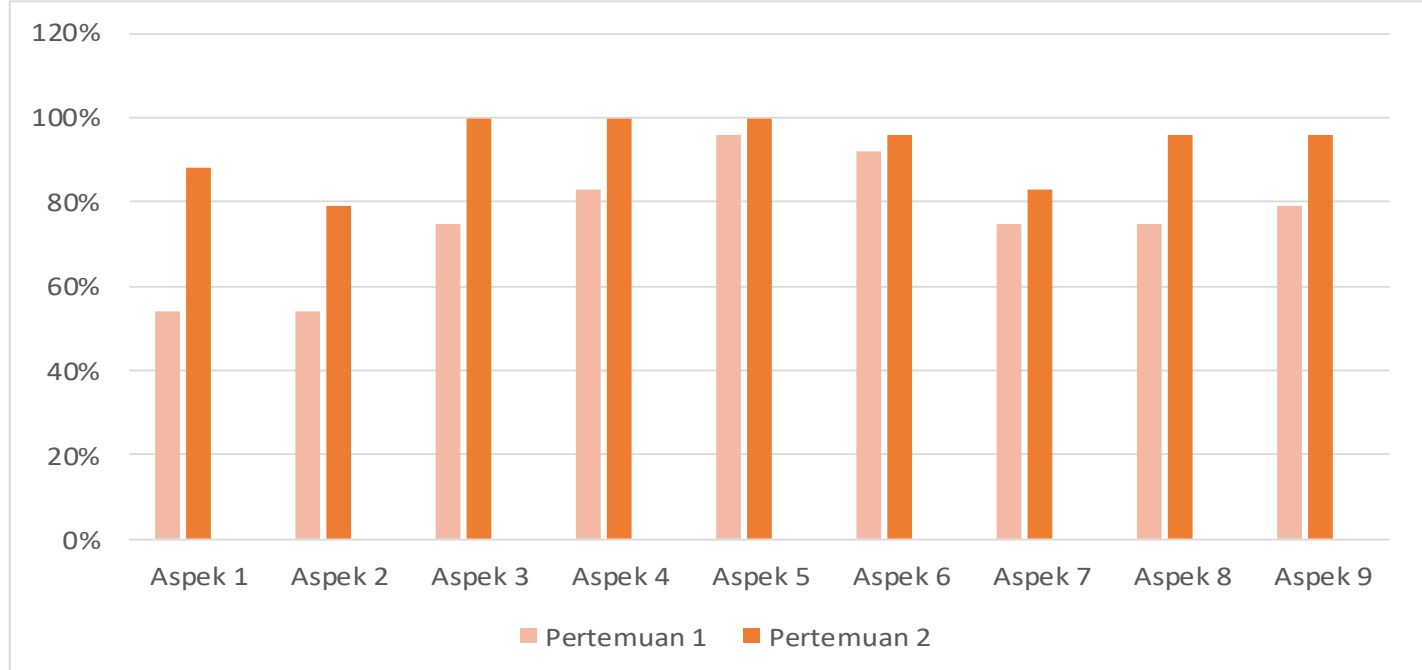

Fig 1:- Student Activity Diagram

The results of observations of student activities from meetings 1 and 2 if related to the adoption criteria for learning adoption (Riduwan, 2011) obtained that the Guided Inquiry-oriented science learning tool that was developed entered into the category of active assessment in learning activities. According to Suyono (2016) regarding learning to find students who support learning related to direct discovery, teachers only encourage students to have experience and conduct experiments that enable them to think critically for themselves (Nur, 2008, p.10). So it can be concluded that teaching materials oriented towards a scientific approach developed by researchers is practically used in the learning process.

\section{The effectiveness of Learning Tool oriented Guided Inquiry}

The effectiveness of Guided Inquiry oriented science learning tools developed by researchers can be seen from the results of learning critical thinking tests and students' responses after participating in online learning. Learners take tests of critical thinking and fill in the online questionnaire responses on the Google Form platform. The results of the pre-test and post-test learning outcomes of the critical thinking tests of participants in the limited trials are presented in Table 8 below.

\begin{tabular}{|c|c|c|c|c|c|c|c|c|}
\hline \multirow{2}{*}{ No } & \multirow{2}{*}{ Name } & \multicolumn{2}{|c|}{ Score } & \multirow{2}{*}{ KKM } & \multicolumn{2}{|c|}{ Completeness } & \multirow{2}{*}{ N-Gain } & \multirow{2}{*}{ Explanation } \\
\hline & & Pretest & Posttest & & Pretest & Posttest & & \\
\hline & \multicolumn{8}{|c|}{ Repetition 1} \\
\hline 1 & AA & 25 & 88 & 70 & $\mathrm{TT}$ & $\mathrm{T}$ & 0,84 & High \\
\hline 2 & BB & 31 & 90 & 70 & TT & $\mathrm{T}$ & 0,85 & High \\
\hline 3 & $\mathrm{CC}$ & 33 & 83 & 70 & TT & $\mathrm{T}$ & 0,74 & High \\
\hline \multirow[t]{2}{*}{4} & DD & 25 & 75 & 70 & TT & $\mathrm{T}$ & 0,67 & Medium \\
\hline & \multicolumn{8}{|c|}{ Repetition 2} \\
\hline 1 & AA & 29 & 85 & 70 & TT & $\mathrm{T}$ & 0,78 & High \\
\hline 2 & $\mathrm{BB}$ & 35 & 77 & 70 & TT & $\mathrm{T}$ & 0,64 & Medium \\
\hline 3 & $\mathrm{CC}$ & 37 & 85 & 70 & TT & $\mathrm{T}$ & 0,76 & High \\
\hline 4 & DD & 71 & 87 & 70 & $\mathrm{~T}$ & $\mathrm{~T}$ & 0,55 & Medium \\
\hline 5 & $\mathrm{EE}$ & 27 & 79 & 70 & $\mathrm{TT}$ & $\mathrm{T}$ & 0,71 & High \\
\hline \multirow[t]{2}{*}{6} & $\mathrm{FF}$ & 73 & 90 & 70 & $\mathrm{~T}$ & $\mathrm{~T}$ & 0,62 & Medium \\
\hline & \multicolumn{8}{|c|}{ Repetition 3} \\
\hline 1 & AA & 33 & 83 & 70 & $\mathrm{TT}$ & $\mathrm{T}$ & 0,75 & High \\
\hline 2 & $\mathrm{BB}$ & 40 & 81 & 70 & TT & $\mathrm{T}$ & 0,68 & Medium \\
\hline 3 & $\mathrm{CC}$ & 35 & 83 & 70 & $\mathrm{TT}$ & $\mathrm{T}$ & 0,74 & High \\
\hline 4 & DD & 31 & 85 & 70 & TT & $\mathrm{T}$ & 0,78 & High \\
\hline \multirow[t]{2}{*}{5} & $\mathrm{EE}$ & 25 & 79 & 70 & TT & $\mathrm{T}$ & 0,72 & High \\
\hline & Average & 52 & 82,5 & 75 & $93 \% \mathrm{TT}$ & $100 \% \mathrm{~T}$ & & \\
\hline
\end{tabular}

Table 8:- Student Learning Outcomes Critical Thinking Data 
Based on the results of critical thinking learning obtained in Table 8 that the value obtained by students between pretest and posttest has increased. The increase can be seen from the N-Gain which is in the medium and high categories. The results of the pretest and posttest analysis can be briefly seen in the following Figure 3 bar diagram.

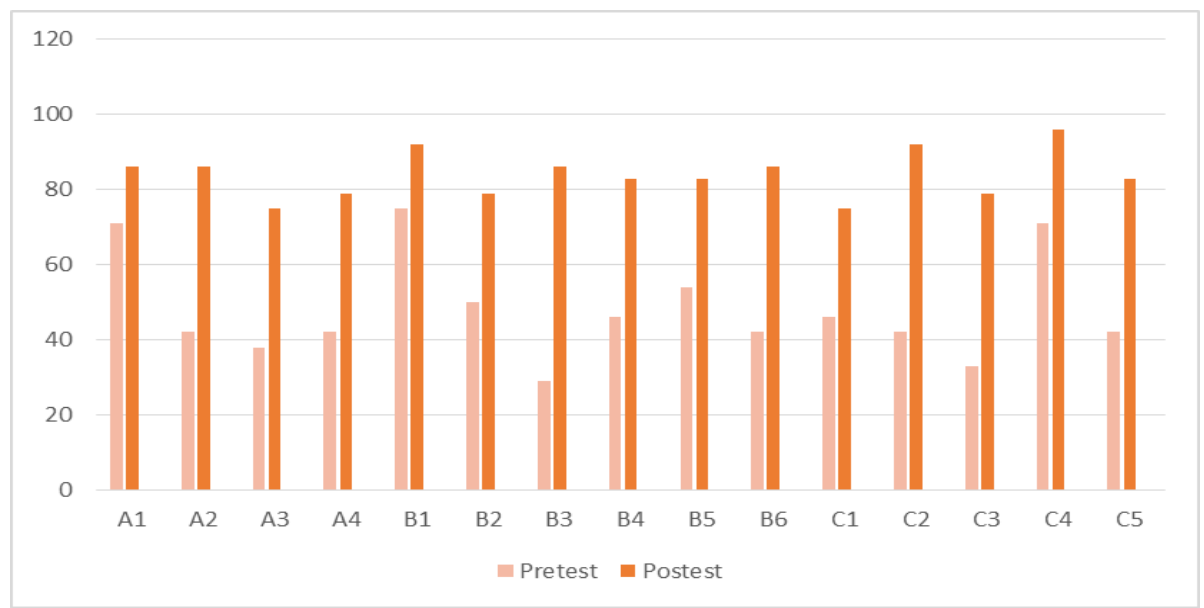

Fig 2:- Pretest and posttest score diagram

\begin{tabular}{|c|c|c|c|}
\hline No & $\begin{array}{c}\text { Category of N- } \\
\text { Gain }\end{array}$ & $\begin{array}{c}\text { Total } \\
\text { students }\end{array}$ & $\begin{array}{c}\text { Percentage } \\
(\boldsymbol{\%})\end{array}$ \\
\hline 1 & Low & 0 & $0 \%$ \\
\hline 2 & Medium & 10 & $67 \%$ \\
\hline 3 & High & 5 & $33 \%$ \\
\hline
\end{tabular}

Table 9:- Recapitulation of Students' Critical Thinking Improvement seen from N-Gain

Based on Table 9 shows that students' critical thinking skills obtained after being given learning treatment by using Guided Inquiry oriented science learning tools as a whole the students are able to complete the learning and have reached the specified KKB that is $\geq 75$. A total of 10 out of 15 received a moderate category of 10 people with an $\mathrm{N}$ gain $\geq 0.5 \%, 67 \%$ and a high category of 5 out of 15 students with an N-gain -0.75 percentage of $33 \%$. From this discussion, it can be concluded that the students' thinking skills have increased.

\section{CONCLUSSION}

Based on the results of the research that has been discussed, it can be concluded that the Natural Science learning tool oriented to Guided Inquiry is feasible (valid, practical, and effective) and improves students' critical thinking skills

\section{SUGGESTION}

Suggestions that can be raised by researchers based on the results of research and discussion are as follows:

1. Critical thinking skills are important to apply in learning because they can increase student activity.

2. Guided Inquiry learning can be developed with larger subjects with other appropriate material.

\section{REFERENCES}

[1]. Akbar, S. 2013. Instrumen Perangkat Pembelajaran. Bandung: Remaja Rosdakarya. Bandung.

[2]. Arends, R.I. 2008. Learning to Teach : Belajar untuk Mengajar. Yogyakarta : Pustaka Belajar

[3]. Arends, R.I .2013. Belajar Untuk Mengajar. Jakarta: Salemba Humanika.

[4]. Arifin, Z. 2019. Evaluasi Pembelajaran. Bandung: PT. Remaja Rosdakarya

[5]. Arikunto, S. 2013. Prosedur Penelitian: Suatu Pendekatan Praktek. Jakarta: Rineka Cipta

[6]. Bundu, Patta. 2006. Keterampilan Proses dan Sikap Ilmiah dalam Pembelajaran Sains. Jakarta : Depdiknas.

[7]. Depdiknas. 2008. Panduan Pengembangan Bahan Ajar. Jakarta: Depdiknas

[8]. Eggen, P.D. and Kauchak. D.P. 1996. Learning and Teaching. 2 nd ed.Needdham Height, Massachussets: Allyn and Bacon.

[9]. Eggen. P.D dan Kauchak. D.P. 2012. Strategi dan Model Pembelajaran. (terjemahan) edisi keenam. Jakarta : Penerbit Indeks

[10]. Ennis, R.H. 1995. Critical Thinking. New York : Prentice Hall

[11]. Facione, P, et al. 2000. The Disposition Toward Critical Thinking : Its Character, Measurement, and Relationship to Critical Thinking Skill. Informal logic vol 20

[12]. Facione, P. 2011. Critical Thinking, What It Is and Why Its Counts. Measured Reason and The California Academic Press

[13]. Fisher, Alex. 2007. Berpikir Kritis Sebuah Pengantar. Jakarta : Erlangga

[14]. Gerald, F. L. 2011. The twin purposes of guided inquiry: guiding student inquiry and evidence based practice. Scan. Vol 30 No 1. pp. 26-41

[15]. Gokhale, A.A. 1995. Collaborative Learning Encjances Critical Thinking. Journal of Technology Education. 
[16]. Gunawan, G., Suranti, N.M.Y., and Fathoroni, F. Ni Made Yeni Suranti, Fathoroni. 2020. Variations of Models and Learning Platforms for Prospective Teachers During The COVID-19 Pandemic Period. Indonesia: Journal of Teacher Education, 1(2), 61-70 Tersedia https://journal.publicationcenter.com/index.php/ijte/article/view/95 Diakses Maret 2020

[17]. Hake. 1999. Analyzing Change/ Gain Score. Tersedia www.physics.indiana.edu/ sdi/AnalyzingChangeGain.pdf Diakses tanggal 10 Oktober 2019

[18]. Hergenhahn dan Olson. 2009. Theories of Learning. Jakarta : Kencana

[19]. Hossoubah. 2007. Develoving Creative and Critical Thinking Skills (terjemahan). Bandung: Yayasan Nuansa Cendia

[20]. Ibrahim, M. 2005. Assesment Berkelanjutan, Konsep Dasar Tahapan Pengembangan dan Contoh. Surabaya : UNESA University Press

[21]. Ibrahim, dkk. 2010. Dasar-Dasar Proses Belajar Mengajar. Surabaya: Unesa University Press

[22]. Ibrahim, M., \& Sukartiningsih, W. 2014. Model Pembelajaran Inovatif melalui Pemaknaan. Surabaya : Unipress

[23]. Indarti, Titik. 2008. Penelitian Tindakan Kelas dan Penelitian Ilmiah. Surabaya : FBS UNESA.

[24]. Krulik, S \& Rudnick. 1999. Innovative Taks to Improve Critical and Creative Thinking Skills. Develoving Mathematical Raesoning in Grades K-12, pp.138-145.

[25]. Kuhltau, C.C., Maniotes, L.K., dan Caspari, A.K. 2007. Guided Inquiry : Learning in 21st Century School. Greenwood Publishing Groip. USA.

[26]. Kuhltau, C.C. and Tood, R.J. 2008. Guided Inquiry. (Online) Tersedia www.icwe.wikispaces.com

[27]. Langrehr, J. 2006. Thinking Skills. Edisi pertama. Jakarta : Gramedia.

[28]. Marlina, AD dan Sugito. 2018. Pengembangan Perangkat Pembelajaran berbasis Inkuiri untuk Meningkatkan Kemapuan Berpikir Kritis dan Tanggung Jawab Siswa. Jurnal Pendidikan. https://journal.uny.ac.id/index.php/jppfa/article/view/2 3631

[29]. Meltem Duran, İlbilge Dökme. 2016. The Effect of the Inquiry-Based Learning Approach on Student's Critical-Thinking Skills. Eurasia Journal of Mathematics, Science, and Technology Education https://eric.ed.gov/?id=EJ1117272 (diakses pada November 2019)

[30]. Mulyasa, H. E. 2007. Menjadi Guru Profesional Menciptakan Pembelajaran Kreatif dan Menyenangkan. Bandung: Remaja Rosda Karya.

[31]. National Science Education Standards (NSES). 1996. National Academy of Science. National Academy Press: Washington, D.C. http://www.nap.edu/openbook.php?record_id=4962 (diakses pada November 2019)

[32]. Nieven N. 1999. Prototype to Read Product Quality: Design Approaches and Tools in Education and Training. Netherland: Springer- Science+Business Media, B.V.
[33]. Nisa, Etik Khoirun. 2016. Pengembangan Perangkat Pembelajaran Fluida Statis dengan Model Pembelajaran Inkuiri Terbimbing untuk Meningkatkan Keterampilan Berpikir Kritis. (Tesis Magister Pendidikan Tidak dipublikasikan). Surabaya : Pasca Sarjana Unesa.

[34]. Noor, J. 2012. Metodologi Penelitian. Jakarta : Kencana Predana Media

[35]. Opara, J. A. \& Oguzor, N. S. 2011. Inquiry Instructional Method and The School Science Curriculum. Journal of Social Sciences, 3 (3), 188-198

[36]. Ormrod, E. J. 2008. Educational Psychology: Developing Learners 6th edition. Upper Saddle River, $\mathrm{NJ}$ : Pearson

[37]. Permendikbud. 2016. Permendikbud Nomor 22 Tahun 2016 Tentang Standar Proses Pendidikan Dan Menengah. Jakarta: Kemendikbud

[38]. Philips, V \& Bond, C. 2004. Undergraduates' Experiences of Critical Thinking Higher Educational Research 7 Developmnent. Journal 23 (3), 277-294

[39]. Prasojo, P. 2016. Pengembangan Perangkat Pembelajaran IPA berbasis inkuiri terbimbing untuk meningkatkan KPS dan Berpikir Kritis. Yogyakarta: Jurnal Matematika dan Sains ttps://journal.uny.ac.id/index.php/jpms/article/view/12 944

[40]. Purwanto. 2009. Evaluasi Hasil Belajar. Yogyakarta: Pustaka Belajar

[41]. Ratumanan, Tanwet Gerson dan Theresia Laurens. 2016. Penilaian Hasil Belajar pada Tingkat Satuan Pendidikan Edisi 3. Yogyakarta: Pensil Komunika

[42]. Santrock, John W. 2011. Perkembangan Anak Edisi 7 Jilid 2. (Terjemahan: Sarah Genis B). Jakarta: Erlangga.

[43]. Slavin, E. R. 2011. Educational Psychology; Theory and Practice. USA : Pearson.

[44]. Solso, R. L., Maclin, O. H., \& Maclin, M.K. 2008. Cognitive Psychology. Jakarta: Erlangga

[45]. Suchman, J.R. 1962. The elementary school training program in scientific inquiry, 1st Edn., University of Illinois, Chicago.

[46]. Sugiyono. 2016. Metode Penelitian Pendidikan. Bandung: Alfabeta/ Jakarta: Rineka Cipta

[47]. Sund, Robert B. dan Trowbridge, Leslie W. 1973. Teaching Science by Inquiry in the Secondary School Second Edition. Columbus: Charles E. Merill Publishing Company

[48]. Suyono \& Hariyanto. 2011. Belajar dan Pembelajaran: Teori dan Konsep Dasar. Bandung: PT. Remaja Rosdakarya

[49]. Uno, Hamzah B. 2008. Perencanaan Pembelajaran. Jakarta : Bumi Askara.

[50]. Wenning, C.J. 2011. Experimental Inquiry in Introductory Physics Courses. JPTO (Journal of Physics Teacher Education Online) Illinois State University Physics Dept. USA. Vol. 6 No. 2, pp.7.

[51]. Yusuf, Muhammad. 2016. Pengembangan Perangkat Pembelajaran IPA Berbasis Keterampilan Proses Untuk Meningkatkan Keterampilan Berpikir Kritis Siswa Sekolah Dasar. (Tesis). Surabaya; Universitas Negeri Surabaya. 